\title{
The Washington Accord and U.S. Licensing Boards
}

\author{
Arif A. Anwar, P.E., M.ASCE${ }^{1}$; and David J. Richards, C.Eng. ${ }^{2}$
}

\begin{abstract}
The Washington Accord known as a mutual recognition agreement between national engineering regulatory bodies was signed in 1989 by six founding signatories. Through this mutual recognition agreement the signatories recognize that the formal educational programs accredited by the respective signatories are substantially equivalent. The stated objective of the Washington Accord is to ease the path of engineering graduates to professional registration or licensing in different jurisdictions. Since 1989, the signatories to the Washington Accord has increased threefold with an additional five countries as currently provisional signatories. This rapid expansion is a reflection of the need for international recognition of educational qualifications and competency across borders in an increasingly globalized world. Engineering accreditation bodies, particularly in developing countries, are proactively seeking recognition and mobility of their graduates. Within this context, the Washington Accord celebrates 25 years and charts a course for the next 25 years. This paper examines in detail the position of the U.S. licensing boards on the Washington Accord. It is concluded that with respect to the U.S. licensing boards, the Washington Accord has made only modest inroads in its first 25 years and needs to set a much more ambitious path for the next 25 to achieve truly reciprocal mobility. DOI: 10.1061/(ASCE)EI.1943-5541.0000246. (C) 2015 American Society of Civil Engineers.
\end{abstract}

\section{Introduction}

Prados et al. (2005) provided an excellent and concise background to the development of engineering accreditation and professional licensure in the United States. Although the legal regulation of engineering practice dates back to 1907 with the passage of the Wyoming Law, accreditation of engineering programs in the United States is reported only to have really gained momentum after 1929 following the Wickenden Report. The Engineers' Council for Professional Development was set up in 1932 to implement the recommendations of the Report. This ultimately led to the formation of the Accreditation Board for Engineering and Technology, Inc. (ABET), a nongovernmental organization that accredits postsecondary education programs in applied science, computing, engineering, and engineering technology. A comprehensive history of the National Council of Examiners for Engineering and Surveying (NCEES) also covers these aspects of engineering accreditation and professional licensure (NCEES 2004).

Uziak et al. (2014) also described accreditation as a fundamental quality-assurance mechanism for engineering education and as an important step for international benchmarking and particularly important for graduates of developing countries. Prados et al. (2005) examined the role of accreditation in facilitating global professional mobility of engineers and concluded that the ABET, through instruments such as mutual recognition agreements, assistance in the development of leader accreditation processes and systems, and substantial equivalency evaluations, has emerged as a leader in

${ }^{1}$ Principal Researcher, Irrigation and Head IWMI Pakistan, International Water Management Institute (Pakistan Office), $12 \mathrm{~km}$ Multan Rd., Chowk Thokar Niaz Baig, Lahore 53700, Pakistan (corresponding author). E-mail: a.anwar@cgiar.org

${ }^{2}$ Professor of Ground Engineering, Faculty of Engineering and the Environment, Univ. of Southampton, Highfield, Southampton SO17 1BJ, U.K. E-mail: D.J.Richards@ @oton.ac.uk

Note. This manuscript was submitted on September 24, 2014; approved on January 12, 2015; published online on February 20, 2015. Discussion period open until July 20, 2015; separate discussions must be submitted for individual papers. This paper is part of the Journal of Professional Issues in Engineering Education and Practice, (C) ASCE, ISSN 1052-3928/ $04015001(6) / \$ 25.00$. providing a useful framework for evaluating equivalence of diverse engineering credentials.

The International Engineering Alliance (2014a) presented a history (in the interest of brevity not restated here) of the Washington Accord, one of the three agreements covering mutual recognition of tertiary-level qualifications in engineering. The Washington Accord recognizes the substantial equivalency of programs accredited by the signatories and recommends that graduates of programs accredited by any of the signatories are recognized by the other signatories. Hanrahan (2014) articulated the stated objective of the Washington Accord by the founding signatories as

"The founding signatories, convinced that their standards and processes were comparable, agreed to recognise each other's accredited programmes. The objective was to ease the path of graduates to professional registration or licensing in different jurisdictions."

This objective of the founding signatories of the Washington Accord resonates with the view held by Uziak et al. (2014) who asserted that accreditation by any signatory to the Washington Accord guarantees international recognition. However, Lucena et al. (2008) previously acknowledged that the increased mobility of engineers creates difficult challenges to country-based systems. Hanrahan (2008) recognized that in several countries the registering and accrediting bodies are distinct-the United States being one such country. Hanrahan (2008) further asserted that under the Washington Accord, the signatories of such countries undertake to ensure that the separate registering body-in the case of the United States the various licensing boards-accepts the accredited programs of other signatories. Leon H. Clary, P.E., L.S. in his President's Report-1995 (NCEES 2004) elaborates that in many countries education, experience, and licensure are under one organization, whereas in the United States these are under three organizations. Clary (NCEES 2004) is of the opinion that the Washington Accord only addresses education and that it is a misconception that the Washington Accord relates in any way to the licensure process.

The founding signatories in 1989 to the Washington Accord were national engineering institutions from Australia, Canada, Ireland, New Zealand, the United Kingdom, and the United States. Subsequently, additional signatories have been added, which 
include professional institutions from Hong Kong China, South Africa, Japan, Singapore, Korea, Chinese Taipei, Malaysia, Turkey, and Russia, with Sri Lanka and India as the new signatories admitted in 2014. There are a number of national institutions with provisional signatory status. Uziak et al. (2014) affirmed that international recognition is becoming increasingly important for graduates in developing countries, which could explain the growing list of signatories to the Washington Accord.

An important point of note is that the U.K. and Ireland are the only two European signatories to the Washington Accord, a point also emphasized by Prichard (2013).

The National Society of Professional Engineers (NSPE 2007) presented a lively historical account of the beginnings of licensure-stemming from a water-resources and irrigation problem. The NSPE (2007) noted that by 1984 all state licensing boards were administering the Fundamentals of Engineering and Principles and Practice of Engineering examinations-a process that the NSPE (2007) reports as started in 1920. This is relevant to this paper because in many ways the current position of the state licensing boards with regard to mutual recognition agreements, including the Washington Accord, is similar to the position of state licensing boards to each other's licenses (reciprocity) of the 1920s.

Prados et al. (2005) identify "How transferable are accreditation criteria and processes across national borders?" as a valid future research question. Anwar and Richards (2013) test in-part the research question posed by Prados et al. (2005) and report on one particular case at the University of Southampton seeking ABET accreditation where educational outcomes and course duration conflicted. The motivation for the current paper is that as the Washington Accord celebrates its 25 years (International Engineering Alliance 2014a), this critical discourse was considered timely and necessary. With more provisional signatories to the Washington Accord awaiting full signatory status it is important that the Washington Accord (and other mutual recognition agreements) is fit for purpose and serves the professional engineering community for the next 25 years taking forward the foresight and vision of the founding signatories. The International Engineering Alliance (2014b) charts the role for the Washington Accord for the next 25 years as "Graduate mobility and recognition through global standards and best practice in accreditation." Therefore, it is important to understand the constraints to graduate mobility and how these may be overcome.

Phillips et al. (2000) described the Washington Accord as a mechanism by which signatories mutually recognize first professional or basic engineering education - although this is debatable in the case of the U.K. and Ireland signatories as these two signatories have included only their integrated master's (MEng) degrees. Phillips et al. (2000) further and quite correctly stated that the licensing and registration bodies are not bound by this agreement. Most signatories of the Washington Accord are both the licensing and registration bodies. However, in the United States, the signatory to the Washington Accord is the ABET, which is only an accreditation body. In the United States, licensing and registration bodies are U.S. state licensing boards. In this paper, the authors expand the scope of Anwar and Richards (2013) and examine in particular the position of each professional engineering licensing board in the United States with regard to the educational qualifications covered under the Washington Accord.

\section{Materials and Methods}

The methodology adopted in this research is a detailed review of the statutes/rules in 52 of the professional engineering licensing boards in the U.S. states and territories as listed in Table 1. In addition to this, materials used in this research included the NCEES Model Law and the NCEES Model Rules, ASCE Policy Statements, ABET rules, Engineering Alliance documentation (which covers all the mutual recognition agreements including the Washington Accord), and other literature as cited in this research paper.

\section{Analysis}

\section{Licensing Board Statutes and Regulations}

For professional licensure applicants who hold an ABETaccredited undergraduate engineering degree, almost all state licensing boards accept this degree as fulfilling the educational requirements of an approved degree. For applicants who hold a nonABET-accredited degree (which includes most non-U.S./foreign degrees), most state licensing boards in this category require that applicants who hold these credentials/qualifications are evaluated by a third party as shown in Table 1 . The majority of state licensing boards require applicants to submit their credentials and/or qualifications to the NCEES for evaluation. Some state licensing boards do not specify the NCEES for evaluation but rather require nonABET degrees to be evaluated by a board-approved organization. A minority of state licensing boards (e.g., Arizona Board of Technical Registration, Idaho Board of Licensure of Professional Engineers and Surveyors, North Carolina Board of Examiners for Engineers and Surveyors) also accept evaluation of non-ABETaccredited credentials/qualifications from evaluation agencies other than the NCEES (e.g., American Association of Collegiate Registrars and Admissions Officers).

The Illinois Board of Professional Engineers/Department of Financial and Professional Regulation is the sole exception to the rule of universal acceptance of ABET-accredited degrees by state licensing board. The Illinois Board states “... shall take into consideration but not be bound by accreditation by the Accreditation Board for Engineering and Technology ..." although the Illinois rules further state "... furthermore upon the recommendation of the Board, has determined that domestic baccalaureate degree engineering programs accredited by the Engineering Accreditation Commission (EAC) of ABET meet the minimum criteria set forth in subsection (a) for an approved engineering program.” Interestingly, Illinois has withdrawn approval for a number of programs from U.S. institutions, which have been approved by the ABET.

It is noteworthy that the Illinois Board rules state that foreign engineering degrees approved by the ABET would also need to be evaluated by the NCEES. The ABET has in the past determined foreign degrees as substantially equivalent. The ABET's substantial equivalency program is obsolete and has been superseded by its international accreditation program. The ABET now undertakes international accreditation of non-U.S. institutions. However, the ABET does not specifically approve programs. If the Illinois Board uses the word approved synonymously with substantial equivalency, then the Illinois rules seem to require updating. Alternatively, if the Illinois Board uses the word approved synonymously with accredited, then interestingly the Illinois Board draws a distinction between ABET non-U.S. accredited degrees and ABET U.S. accredited degrees. Although perhaps a slightly moot point since ABET has withdrawn its substantial equivalency program, the Illinois Board Rule 38.VIIIb 1380.210 (c) (3) states

"The Division, upon the recommendation of the Board, does not recognize ABET 'substantially equivalent' programs as meeting 
Table 1. Professional Engineering Boards Reviewed

\begin{tabular}{|c|c|c|}
\hline Number & $\begin{array}{l}\text { U.S. state } \\
\text { or territory }\end{array}$ & Non-U.S. educational qualification \\
\hline 1 & Alabama & NCEES evaluation \\
\hline 2 & Alaska & Not specified \\
\hline 3 & Arizona & NCEES evaluation and others \\
\hline 4 & Arkansas & Not specified \\
\hline 5 & California & NCEES evaluation \\
\hline 6 & Colorado & Not specified \\
\hline 7 & Connecticut & NCEES evaluation \\
\hline 8 & Delaware & Board evaluation \\
\hline 9 & $\begin{array}{l}\text { District of } \\
\text { Columbia }\end{array}$ & NCEES evaluation \\
\hline 10 & Florida & $\begin{array}{l}\text { NCEES, Josef Silny \& } \\
\text { Associates evaluation }\end{array}$ \\
\hline 11 & Georgia & NCEES evaluation \\
\hline 12 & Guam & NCEES evaluation \\
\hline 13 & Hawaii & Board evaluation \\
\hline 14 & Idaho & NCEES, AACRAO evaluation \\
\hline 15 & Illinois & NCEES evaluation \\
\hline 16 & Indiana & NCEES evaluation \\
\hline 17 & Iowa & Board evaluation \\
\hline 18 & Kansas & Evaluation by board-approved organization \\
\hline 19 & Kentucky & NCEES evaluation \\
\hline 20 & Louisiana & Board-approved organization \\
\hline 21 & Maine & NCEES evaluation \\
\hline 22 & Maryland & Evaluation by board-approved organization \\
\hline 23 & Massachusetts & NCEES evaluation \\
\hline 24 & Michigan & Board evaluation \\
\hline 25 & Minnesota & NCEES evaluation \\
\hline 26 & Mississippi & NCEES evaluation \\
\hline 27 & Missouri & Not specified \\
\hline 28 & Montana & Evaluation by board-approved organization \\
\hline 29 & Nebraska & NCEES evaluation \\
\hline 30 & Nevada & NCEES evaluation \\
\hline 31 & New Hampshire & NCEES evaluation \\
\hline 32 & New Jersey & Not specified \\
\hline 33 & New Mexico & Board evaluation \\
\hline 34 & New York & Board evaluation \\
\hline 35 & North Carolina & NCEES, AACRAO \\
\hline 36 & North Dakota & Board evaluation \\
\hline 37 & Ohio & NCEES evaluation \\
\hline 38 & Oklahoma & NCEES evaluation \\
\hline 39 & Oregon & NCEES evaluation \\
\hline 40 & Pennsylvania & NCEES evaluation \\
\hline 41 & Puerto Rico & - \\
\hline 42 & Rhode Island & Board evaluation \\
\hline 43 & South Carolina & Board evaluation \\
\hline 44 & South Dakota & NCEES evaluation \\
\hline 45 & Tennessee & Evaluation by board-approved organization \\
\hline 46 & Texas & Evaluation by board-approved organization \\
\hline 47 & Utah & NCEES evaluation \\
\hline 48 & Vermont & NCEES evaluation \\
\hline 49 & Virginia & Board evaluation \\
\hline 50 & Virgin Islands & Board evaluation \\
\hline 51 & Washington & NCEES evaluation \\
\hline 52 & West Virginia & Evaluation by board-approved organization \\
\hline 53 & Wisconsin & Board evaluation \\
\hline 54 & Wyoming & NCEES evaluation \\
\hline
\end{tabular}

Note: AACRAO = American Association of Collegiate Registrars and Admissions Officers.

the minimum criteria set forth in subsection (a) for an approved engineering program and are, therefore, not approved."

For foreign engineering degrees, the Board of Professional Engineers, New Hampshire, Rule 303.01 (b) (1) states

"Applicants possessing a 4-year EAC/ABET equivalent, foreign engineering degree which consists of an engineering program which has a successful ABET site visit shall have 4 years engineering experience satisfactory to the board";

Rule 303.01 (b) (1) presumably applies to the ABET's substantial equivalency program, which is now obsolete and has been superseded by the ABET's international accreditation program. For foreign engineering (non-ABET accredited) graduates, the New Hampshire Board Rule 303.01 (b) (5) requires the degree to be evaluated by the NCEES and if the degree is deemed favorable, the graduate must then fulfill 8 years of qualifying experience to be eligible for professional licensure. In contrast to graduates of an ABET-accredited engineering program, the requirement is 4 years of qualifying experience. This rule is not unique to the New Hampshire Board alone, rather the majority of state licensing boards require 8 years of qualifying experience for foreign engineering (non-ABET accredited) graduates.

The Pennsylvania State Registration Board for Professional Engineers, Land Surveyors and Geologists Rule 49 Section 37.31 a 1 iv) states "Graduation from a foreign undergraduate or graduate, or both, engineering curriculum that was substantially equivalent to an ABET-accredited curriculum, as shown by an evaluation of the candidate's credentials by the NCEES's credentials evaluation division." It is interesting to note that although the Washington Accord's very purpose is to establish substantial equivalency of programs accredited by the signatories, the Pennsylvania Board as with most other licensing board still requires the credentials to be evaluated by the NCEES.

The Tennessee Board of Architectural and Engineering Examiners accepts undergraduate engineering degrees accredited by the $\mathrm{ABET}$ or those that have been determined to be substantially equivalent to an ABET-accredited degree. Again this refers to the now obsolete ABET substantial equivalency program.

Only a very small number of state licensing boards explicitly acknowledge the Washington Accord in their statutes and rules. State licensing boards that fall into this category are the Texas Board of Professional Engineers, the Idaho Board of Licensure of Professional Engineers and Professional Land Surveyors, and the South Carolina Department of Labor, Licensing and Regulation. This minority group of licensing boards considers any degree covered by the Washington Accord as an acceptable qualification toward the educational eligibility requirements for licensure.

This throws up a unique anomaly with respect to the European signatories, namely, the U.K. and Ireland, of the Washington Accord. Anwar and Richards (2013) established that for the U.K., only MEng degrees are covered under the Washington Accord, whereas the U.K. BEng degrees are not recognized by the Washington Accord. This fact was restated by Prichard (2013) who as the Chief Executive Officer of the Engineering Council (U.K.) is a significant authority on the subject. Engineers Ireland (2014), the second European signatory to the Washington Accord, explicitly states that "... programmes listed under Chartered Engineer meet the Washington Accord ...." For Ireland, just as with the U.K., programs that meet the educational requirements for a Chartered Engineer, and hence the Washington Accord, are master-level programs known colloquially as MEng programs. Therefore, by inference, the Texas, Idaho, and South Carolina Boards will only accept European MEng degrees as an acceptable qualification toward the eligibility requirements for licensure. This is reinforced by the fact that many state licensing boards require an undergraduate engineering curriculum to be of 4 years in duration, and also that the ABET requires an engineering degree to be of 4 years in duration (ABET, personal communication, 2011). These licensing boards do not give credit for the U.K. master-level qualification beyond that of the U.S. bachelor's qualification, that is, they are considered on par. By contrast, most licensing boards explicitly 
give credit (in the form of reducing work-experience requirements) to candidates who hold an ABET-accredited master's degree. The anomaly of U.K. engineering degrees and the Washington Accord is even more complicated with engineering bachelor's degrees from Scotland. Although Scotland is part of the U.K., an engineering bachelor's degree in Scotland is 4 years in duration as opposed to the 3-year duration in England and Wales. However, as the signatory to the Washington Accord, the U.K. Engineering Council represents the entire U.K. (including Scotland), and therefore, engineering bachelor's degrees from Scotland are also not recognized by the ABET under the Accord. As with all other (non-European) Washington Accord signatories, it is the bachelor's qualifications that are considered comparable to the U.S. bachelor's qualification and as acceptable qualifications toward the eligibility requirements for licensure.

The Minnesota Administrative Rules (2014) do not make explicit reference to the Washington Accord, but a U.K. Chartered Engineer (CEng) under Rule 1800.2800 (B) would be exempt from the requirement of passing the Fundamentals-of-Engineering (FE) Examination. The New Mexico Board of Licensure for Professional Engineers and Professional Surveyors does not recognize any mutual recognition agreements. Under the 2012 New Mexico Engineering and Surveying Practice Act (Section 61-23-14.1), an engineer licensed in a foreign country who can demonstrate the license was obtained based on standards at least equal to that those required by the 2012 New Mexico Engineering and Surveying Practice Act and can demonstrate competence may be licensed by endorsement. The North Dakota State Board of Registration for Professional Engineers and Land Surveyors, Iowa Professional Licensing Bureau, and Rhode Island State Division of Design Professionals have a similar position on engineers with regard to registration to practice in a foreign (non-United States) country to that of the New Mexico.

A number of licensing boards recognize degrees accredited by the Canadian Engineering Accreditation Board as fulfilling the educational requirements for professional licensure. The Illinois Board recognizes the "... Mutual Recognition Program agreement between ABET and the Canadian Engineering Accrediting Board (CEAB) of the Canadian Council of Professional Engineers is considered to have met the minimum criteria as equivalent to the ABET accredited programs and are, therefore, approved, subject to review." The Illinois Board does not explicitly recognize the Washington Accord. The Mississippi Board, South Carolina Board, South Dakota Board, and Utah Division of Occupational and Professional Licensing have a similar position on programs accredited by the CEAB to the Illinois Board. This is noteworthy because Canada is a signatory of the Washington Accord, and therefore, degrees accredited by the Engineers Canada are recognized by U.S. licensing boards by explicit reference in board rules and statutes, and additionally where applicable by recognition of the Washington Accord. It is also interesting to note that there are more state licensing boards that acknowledge the Canadian Engineering Accreditation Board rather than the Washington Accord.

\section{NCEES Model Law and Model Rule and ASCE Policy Statement 465}

The stated aim of the NCEES Model Law (NCEES 2013a) is to assist legislative counsel in preparing new laws or amendments to existing laws. The proportion of the NCEES Model Law that is adapted into state licensing board statutes varies and is difficult to quantify. Some state licensing boards have adopted verbatim sections from the NCEES Model Law, whereas others paraphrase the NCEES Model Law. What is clear however is that the NCEES
Model Law does bear significant influence on state licensing board statutes. The Model Law makes no reference to the Washington Accord or indeed any mutual recognition agreement. The NCEES Model Rule (NCEES 2013b) 230.10.A.2 only refers to foreign qualifications deemed substantially equivalent by the licensing board to an EAC/ABET-accredited degree. As discussed in the previous paragraph, most licensing boards delegate the task of establishing equivalency to the NCEES's Credentials Evaluation service.

As the Washington Accord looks toward the next 25 years, the Accord needs to be cognizant of the implications of the ASCE Policy Statement 465 (ASCE 2014), which states that the "... attainment of an engineering body of knowledge for entry into the practice of engineering at the professional level, i.e., practice as a licensed professional engineer, through appropriate engineering education and experience ..., which would require a combination of the following:

- A baccalaureate degree in engineering; and

- A master's degree in engineering."

The recommended time frame stated by the ASCE Policy Statement 465 for this raising the bar is no earlier than 2020. The NCEES Model Law (NCEES 2013a) also incorporates the requirement of a candidate seeking professional licensure to have an engineering master's level qualification. Although the NCEES Model Law recommends this law to come into effect from January 1, 2020 , the footnote acknowledges that the implementation may vary between jurisdictions and recommends an 8-year period for implementation. The implementation of Policy Statement 465 into licensure statutes is by no means a foregone conclusion. Walker (2012) described there are two cultures of engineering - the professional independence interest versus the business interest with strong arguments presented by the proponents and opponents. Richards et al. (2011) examined the sentiments of business owners, university professors, and state licensing boards toward ASCE Policy Statement 465. Importantly, in the context of this paper is the sentiment of licensing boards toward Policy Statement 465, and Richards et al. (2011) found that $46 \%$ of state licensing board's chairs support and $38 \%$ oppose ASCE Policy Statement 465, with $16 \%$ undecided. The support from licensing board's chairs is lower than that of academic leaders at $60 \%$, but higher than that of the American Council of Engineering Companies (business leaders) at 16\%. Therefore, whether or not the ASCE Policy Statement 465 finds its way into the statutes of state licensing boards remains an open question.

The ASCE Policy Statement 465 may not pose a particular problem for most European master's degrees. In fact, at the time of this writing, three institutions in Spain and one in Germany hold ABET-accredited engineering master's programs. Hence, it can be envisaged that the Washington Accord could be amended to cover the European engineering master's degree-however, the issue of European bachelor's degree described earlier remains. The ASCE Policy Statement 465 may pose a challenge for the U.K. and Ireland where an engineering master's program is 1 calendar year ( 3 semesters in duration) rather than the more typical 2 academic years (4 semesters). The ASCE Policy Statement 465 qualifies the requirement of a master's degree as no less than 30 credits. In the U.K., a typical engineering master's degree is 90 European Credit and Transfer System. Therefore, this could become a subject of debate between these two credit systems.

\section{Conclusions and Recommendations}

This research paper shows that despite 25 years of the Washington Accord, the majority of state licensing boards in the United States 
do not explicitly acknowledge mutual recognition agreements entered into by the various national bodies responsible for accrediting national engineering degree programs. In the United States almost without exception, all state licensing boards require any engineer with a non-U.S. engineering degree to obtain evaluation of their degree. The agency of choice for most state licensing boards for the evaluation of foreign (non-United States) credentials is the NCEES.

A small minority of state licensing boards do acknowledge the Washington Accord and accept an engineering degree obtained from a Washington Accord signatory country as fulfilling the educational requirements toward professional licensure. This in fact is the starting point for signatories of the Washington Accord, if this accord is to be relevant and a useful instrument that (paraphrasing from the objective stated by the founding signatories) is to ease the path of graduates to professional registration or licensing in different jurisdictions. The signatories of the Washington Accord need to use as exemplars the Texas Board of Professional Engineers, Idaho Board of Licensure of Professional Engineers, and Professional Land Surveyors and South Carolina State Board of Registration for Professional Engineers and Surveyors for other state licensing boards to recognize the Washington Accord and include it in their statutes/rules. Another exemplar is the Illinois Board of Professional Engineers/Department of Financial and Professional Regulation, which also recognizes a mutual recognition agreement—albeit that between the ABET and the $\mathrm{CEAB}$. A low-hanging fruit for the signatories of the Washington Accord would hence be the Illinois Board. Here, it would be a case of making a point that the Illinois Board includes a second mutual recognition agreement, namely, the Washington Accord in its rules. In addition, the signatories of the Washington Accord should seek to include reference to this Accord (and possibly other mutual recognition agreements) into the NCEES Model Law and Model Rules.

For the European signatories of the Washington Accord, namely, the U.K. and Ireland, there is an additional challenge as the bachelor's (BEng) degree is specifically excluded from the Washington Accord. Interestingly, should Scotland have achieved independence following a positive endorsement of the referendum on this question, Scotland's 4-year engineering bachelor's degree would fulfill the ABET requirements with educational outcomes being substantially similar to engineering bachelor's degree from England, Wales, and Northern Ireland. As it stands for the U.K., the Washington Accord only recognizes the integrated master's (MEng) degree. The ABET website states (ABET 2014) "Graduates of programs based in the United Kingdom and Russia: Please email ABET's International Relations Manager to determine if the program you graduated from is recognized by the Washington Accord," whereas for almost all other signatory countries a simple checklist is provided. This lack of clarity does not sit comfortably with the role identified for the Washington Accord over the next 25 years of graduate mobility and recognition. Based on the evidence presented in this paper, the authors are of the opinion that the impasse here is that European bachelor's degrees are of 3-year duration, whereas outside of Europe (including the United States) bachelor's degrees are of 4-year duration. Perhaps then, the only solution is for a European engineering graduate is to accept that a European bachelor's degree in engineering does not fulfill the educational requirements toward professional licensure in the United States and such graduates should expect to take additional courses/credits.

The signatories to the Washington Accord need to have contingency plans should the minimum educational requirement for licensure become a master of engineering degree enter the statues of licensing boards in 2020 or thereafter. The International
Engineering Alliance needs to be cognizant of a fast-changing world in which individual institutions are becoming more international and may overtake the International Engineering Alliance. Since ABET started offering accreditation services outside the United States in 2007, 365 academic programs at 72 institutions in 23 other nations have achieved ABET accreditation. The NCEES has changed the Fundamentals of Engineering examination to a computer-based test delivered through Pearson VUE test centers. The NCEES offers examinations internationally in Canada, Egypt, Sharjah, Japan, Korea, Saudi Arabia, and Turkey. Furthermore, Saudi Arabia rather than becoming a signatory to any mutual recognition agreement for its own territorial degrees has adopted the U.S. model of ABET Accreditation and PE licensure. It is in this fast-moving environment that the International Engineering Alliance needs to ensure that its instruments such as mutual recognition agreements remain relevant. The alternative model is that institutions from signatory countries such as Engineers Canada go-it-alone and obtain explicit recognition in state licensing boards and statutes, which would certainly render mutual recognition agreements less relevant in the United States.

\section{References}

ABET (Accreditation Board for Engineering and Technology). (2014). "Is your program recognized by the Washington accord?" (http://www.abet .org/recognized-by-washington-accord// (Aug. 20, 2014).

Anwar, A. A., and Richards, D. J. (2013). "Is the USA set to dominate accreditation of engineering education and professional qualifications?" Proc. Inst. Civ. Eng., 166(CE1), 42-48.

ASCE. (2014). "Policy statement 465-Academic prerequisites for licensure and professional practice." 〈http://www.asce.org/issues-and -advocacy/public-policy/policy-statement-465-academic-prerequisites -for-licensure-and-professional-practice) (Dec. 16, 2014).

Engineers Ireland. (2014). "Chartered engineer accredited programmes." 〈http://www.engineersireland.ie/services/accredited-courses/chartered -engineer.aspx $\rangle$ (Aug. 17, 2014).

Hanrahan, H. (2008). "The Washington accord: History, development, status and trajectory." 7th ASEE Global Colloquium on Engineering Education, Cape Town, South Africa.

Hanrahan, H. (2014). "Dr Hu Hanrahan's speech notes at Washington accord dinner." 〈http://www.ieagreements.org/25_years/> (Aug. 16, 2014).

International Engineering Alliance. (2014a). "25 years Washington accord." 〈http://www.ieagreements.org/25_years/〉 (Aug. 16, 2014).

International Engineering Alliance. (2014b). "PowerPoint presented at the 25 years Washington accord dinner." 〈http://www.ieagreements.org/ 25_years/> (Aug. 16, 2014).

Lucena, J., Downey, G., Jesiek, B., and Elber, S. (2008). "Competencies beyond countries: The reo-organization of engineering education in the United States, Europe and Latin America.” J. Eng. Educ., 97(4), 433-447.

Minnesota Administrative Rules. (2014). Chapter 1800, Licensing and operation, Board of Architecture, Engineering, Land Surveying, Landscape Architecture, Geoscience, and Interior Design, 〈https:// www.revisor.mn.gov/rules/?id=1800\&view=chapter\#rule.1800.2800 (Aug. 17, 2014).

NCEES (National Council of Examiners for Engineering and Surveying). (2004). The history of the National Council of Examiners for Engineering and Surveying: 1920-2004, 3rd Ed., J. A. Corley, ed.

NCEES (National Council of Examiners for Engineering and Surveying). (2013a). "Model law." /http://cdn3.ncees.co/wp-content/uploads/2012/ 11/Model-Law-2013.pdf (Sep. 20, 2014).

NCEES (National Council of Examiners for Engineering and Surveying). (2013b). "Model rules." 〈http://cdn3.ncees.co/wp-content/uploads/ 2012/11/Model-Rules-2013.pdf〉 (Sep. 20, 2014).

NSPE (National Society of Professional Engineers). (2007). "Century." /http://www.nspe.org/sites/default/files/resources/pdfs/pemagazine/ june2007_the_professional_engineering.pdf $\rangle$ (Sep. 5, 2014). 
Phillips, W. M., Peterson, G. D., and Aberle, K. B. (2000). "Quality assurance for engineering education in a changing world." Int. J. Eng. Educ., 16(2), 97-103.

Prados, J. W., Peterson, G. D., and Lattuca, L. R. (2005). "Quality assurance of engineering education through accreditation: The impact of engineering criteria 2000 and its global influence.” J. Eng. Educ., 94(1), 165-184.

Prichard, J. (2013). "Discussion to 'Is the USA set to dominate accreditation of engineering education and professional qualifications?" Proc. Inst. Civ. Eng., 166(CE2), 56.
Richards, P. W., Williams, G., Schultz, G. G., and Nelson, E. J. (2011). "Present sentiment about ASCE Policy Statement 465 among business owners, university professors and state licensing boards." J. Prof. Issues Eng. Educ. Pract., 10.1061/(ASCE)EI.1943-5541.0000041, 122-126.

Uziak, J., Oladiran, M., Walczak, M., and Gizejowski, M. (2014). "Is accreditation an opportunity for positive change or a mirage?" J. Prof. Issues Eng. Educ. Pract., 10.1061/(ASCE)EI.1943-5541.0000172, 02513001.

Walker, H. W. (2012). "Policy 465: Latest struggle in the 'Revolt of the Engineers'." J. Prof. Issues Eng. Educ. Pract., 10.1061/(ASCE)EI .1943-5541.0000113, 283-288. 